\title{
COMMUNICATING WITH BRAND NAMES IN THE SUSTAINABLE FINNISH FASHION INDUSTRY*
}

Keywords: brand names, sustainability, circular economy, Finnish, cognitive onomastics, textile industry

\section{INTRODUCTION}

It is a well-known fact that the global textile industry has a significant environmental impact since the current system for producing and distributing clothing exhausts natural resources. Greenhouse gas emissions from textile production exceed those of all international flights and seafaring combined, and the majority of plastic microfibers entering oceans come from washing garments. The clothing market is growing rapidly as people all over the world are purchasing more clothes than they would need and use. "Fast fashion" has made trendy dressing achievable to the masses, irrespective of economic status. Trends change fast, and clothes are only used for a short period of time, after which the materials are lost to landfill or incineration (EMF, 2017).

In recent years, there has been a growing awareness of the textile industry's negative environmental impact among customers, a factor which has directed more and more clothing companies towards aligning themselves with the principles of sustainability. There are many new clothing companies - designers, fabric and garment manufacturers and retailers — which have built their activities

* This work is part of a project called "Circular Economy Catalysts: From Innovation to Business Ecosystems". The term catalyst is a metaphor for an enabler that serves as a positive driving force for circular economy transition. Language is one of the catalysts that are investigated in the project. The project is being carried out in co-operation between various Finnish universities and is funded by the Strategic Research Council of the Academy of Finland (CICAT2025). Acknowledgments to my colleagues Marileena Mäkelä and Ville Virsu for their valuable comments on the manuscript. 
on sustainability and the circular economy from the start. Not only are there economic reasons behind this, but also ideological ones: companies want to appeal to the values held by their customers, and entrepreneurs themselves may have strong ideological motives as well.

This study focuses on the textile industry in Finland. As a member of the European Union, Finland has committed itself to a comprehensive EU strategy for a circular economy, which ensures that old textiles and scraps are collected in their own bins for reuse in all member states, by 2025 at the latest (see Finnish Government, 2019, p. 44). The EU Circular Economy Action Plan also explains that textile products would be made of secondary raw materials instead of virgin ones, and that their production would not use so many non-renewable resources (e.g. oil, fertilizers and chemicals). It also stresses that businesses and private consumers should be able to choose sustainable textiles and have easy access to reuse and repair services (EU, 2020; Šajn, 2019).

The aim of this study is to find out whether ideological values can be seen in the names of sustainable textile companies, and if so, in what ways the brand names convey the notion of environmental sustainability. I will study the semantics of commercial names from both the cognitive and pragmatic-discursive viewpoints. In this context, I use the concepts of company name and brand name as synonyms. I define a brand according to Park et al. as "a value-generating entity (name) relevant to both customers and the brand-owner" (2016, p. 4).

\section{THEORETICAL VIEWPOINTS}

The study of commercial naming is one of the newer branches of onomastics, and it focuses on company and brand names. Linguistic research on commercial names has increased since the 1990s, first mainly in Europe, but it is currently growing in all continents and numerous languages. ${ }^{1}$ Methodologically, there has been a search for suitable directions in the field, because toponymic or anthroponymic research methods, which traditionally concentrate on etymologies and name giving circumstances, are not appropriate for commercial names, as these have an explicitly communicative function, which is to deliver meanings synchronically in use. Hence, cognitive and functional linguistics as well as socio-onomastics, discourse studies, and pragmatics offer a good basis for the semantic study of names (Sjöblom, 2016; Teutsch, 2008.)

${ }^{1}$ The worldwide range of research is to be seen, for example, in the publications of the Names in the Economy conferences, which have been organized approximately every third year since 2006 in different European countries (see Sjöblom, 2016). 
The methods of this study rest upon cognitive-functional onomastics, and the basic perspective is discursive. To obtain a comprehensive view of how names are semantically connected with the surrounding society and ideologies, we need to look at our data from both a cognitive perspective (a subjective viewpoint), and in relation to the functions and discourses that the names are used in (an intersubjective or pragmatic viewpoint). As part of the rhetorical meanings the names convey, we not only need to look at the expressions included in the names but also at the languages of these expressions.

\section{Cognitive perspective}

According to all cognitive linguistic theories, language is interrelated with human cognition. Language has two key functions: symbolic, which means that it encodes our thoughts, and interactive, which means that it allows us to transmit (by sender) and decodes (by receiver) thoughts. The manner in which language does this is by using symbolic units, which consist of forms and meanings. A conceptual domain is a body of knowledge within our cognitive system. A domain contains and organizes ideas and experiences related to one another, and it is the encyclopedic scope for the semantic description of an expression (Evans \& Green, 2006; Langacker, 1987).

According to cognitive metaphor theory by George Lakoff and Mark Johnson (1980), mapping information between two different domains ${ }^{2}$ is an elementary feature of language: it creates novel conceptual structures and a novel expressive effect. It is necessary, especially when we need to understand and describe abstract concepts. We systematically structure them in terms of conceptual domains deriving from our experience of the behavior of physical objects. The concept we need to understand is the target domain (e.g. TIME), and the concepts we use to describe it are found in the source domain (MOVEMENT, for instance in phrases such as time is running or hours go slowly) (Lakoff \& Johnson, 1980).

From a cognitive perspective, proper names construct meanings of language to an equal degree as other linguistic elements (morphemes, words, phrases etc.). The difference between the meaning of proper and common nouns is that proper names select one from many similar entities and are individualizing, while common nouns link many similar entities together and are categorizing (Sjöblom, 2006). Cognitive theories enable the examining of brand names as symbolic units, which launch a process of cognitive operations, such as mapping, and result in the generation of conceptual associations. (Sjöblom, 2016; Pérez Hernández, 2011, 2013). Names have a special task in business communication. A brand

\footnotetext{
${ }^{2}$ Some cognitive theories call this kind of process blending.
} 
name does not just refer to an object but also conveys meanings important to the sender (entrepreneur), and, like a bridge between a producer and a customer, it fulfils interactive functions, such as persuading the customers (Sjöblom, 2016; Zilg, 2013; Teutsch, 2008).

Cognitive analysis describes what kind of relationship there is between the meaning of the expression included in the name and its referent - in this case, the company. This method not only requires careful semantic analysis of the name form, but also sufficient background details about the referent. To be more precise, the semantic analysis of commercial names considers what the cognitive domains of the name structure are in relation to the cognitive domains evoked by the referent. This relationship can be described as a semantic scheme. In case the scheme is direct, the elements of a name directly convey the meanings related to the referent; for instance, the element can be a word expressing the branch of business (e.g. clothing, design) or the owner's personal name. In case the scheme is indirect, the meaning of the name form has a metaphoric, metonymic or symbolic relationship to the referent (e.g. Apple, Nike). Some company names are neologisms, with many meaningful elements compressed into a short form (e.g. Novosat $<$ Latin novus 'new' + satellite), or with a name form that has no semantic relation to the referent at all (e.g. IBM) (Sjöblom, 2006, 2016).

\section{Functional and discursive perspective}

To complete the overall picture we get from analyzed names, the model needs to include the examination of the sociocultural functions of the name forms. The idea behind this is that producing meanings is never an intrinsic value but the meanings of language always have some function - names are what they are because of what they do (Sjöblom, 2016). In connection with the analysis of the semantic schemes of our data, we need to consider what function meaningful names have in marketing discourse, which is one of the most important discourses brand names are made for.

Discourses reflect and construct the surrounding society and its power relations. A discourse is a cultural frame in which rhetoric is the linguistic means of defining individual and collective identities and creating common ground between the parties of communication (Rosteck, 1999; Virsu, 2012). In marketing discourse, we can say that rhetoric calls the recipient to relate to a 'we' group that the product represents.

Names act as part of the rhetoric of marketing discourse. They can call forth identities that rise from ideologies, and they create cultural narratives through repeated use, acting either as a set for accredited ideologies or as a sign of 
empowerment (Vanguri, 2016; Lowry, 2016; Montes Fernández, 2008). Therefore, in this context, a name that has a semantic connection to sustainable development can manifest a company's ideological identity. Using this kind of name either allures customers who have similar ideologies or makes the ecological ideology gradually more familiar and acceptable to the general public.

\section{Language choice as a rhetorical choice}

Language choice is a significant aspect regarding the messages that company names convey. It is not a trivial question if the name is in the country's native language, in English as a lingua franca, or in some other foreign language. The choice of language is one kind of statement about brand identity to which consumers can relate. It can also be a discursive way to confirm certain language beliefs and practices in the community (see Mattfolk, 2017).

Nowadays, thanks to the Internet, even the smallest shops have an opportunity to sell their products to customers on the other side of the world. Global markets have made English the global language of business, and this naturally has made English gain ground in appearing in commercial names everywhere. (e.g., Mattfolk, 2017; Montes Fernández, 2008). The use of English in names can be associated with qualities such as internationality, innovation, attractiveness, modernity, and urban life. Other Western languages, such as French, Italian, Spanish, Latin, German or the Nordic languages, have different qualities regarding the associations of names, such as elegance, design, casualness or diligence. On the other hand, company names found in the West in an African or Asian language can transmit a feeling of exoticism or maybe even of a different mindset. It is also quite typical for a name to be a phrase or a neologism, which is the result of a merger of two or more foreign elements, and elements of a local language or even a dialect. Names can also consist of quasi words of no real language (Ainiala et al., 2012; see also Montes Fernández, 2008).

Some studies have shown that young people may take a less negative approach toward English or other foreign elements in names than older people (Bergien, 2008). However, there are also other factors than a consumer's age that affect the attitudes toward different languages in brand names. Language choice may convey meanings that reinforce brand benefits for the customer. By buying a certain brand, customers may seek, for example, security, excitement, or respect. If they see the brand as a solution to their own - or worldwide - problems, they feel empowered. Customers who value security and confidence may look at names in a local language more positively, because the native language can reduce fear by expressing familiarity and reliability. (See Park et al., 2016). 


\section{DATA AND METHODS}

The data of this study consist of 114 brand names of Finnish textile and fashion companies, whose activities are, in one way or another, affiliated with sustainable circular economy. I have taken most of these names (103) from a list compiled by a national research project called FINIX (see www.finix.aalto.fi), whose aim is to help co-create resource-wise textile business in Finland. The names in this study have been supplemented with 11 names of responsible textile companies that are not yet on the FINIX list but are highly likely to fulfil the EU objectives. ${ }^{3}$

The majority of sustainable companies in question are very new: 84 companies (74\%) have been incorporated between 2012 and 2019, and only $11(10 \%)$ are from the $20^{\text {th }}$ century - the oldest being established in 1917 (see figure). Apparently, the recent discussion about environmental issues and sustainable development has especially affected the modus operandi of new firms, whereas older firms are adopting these ideas and values slowly.

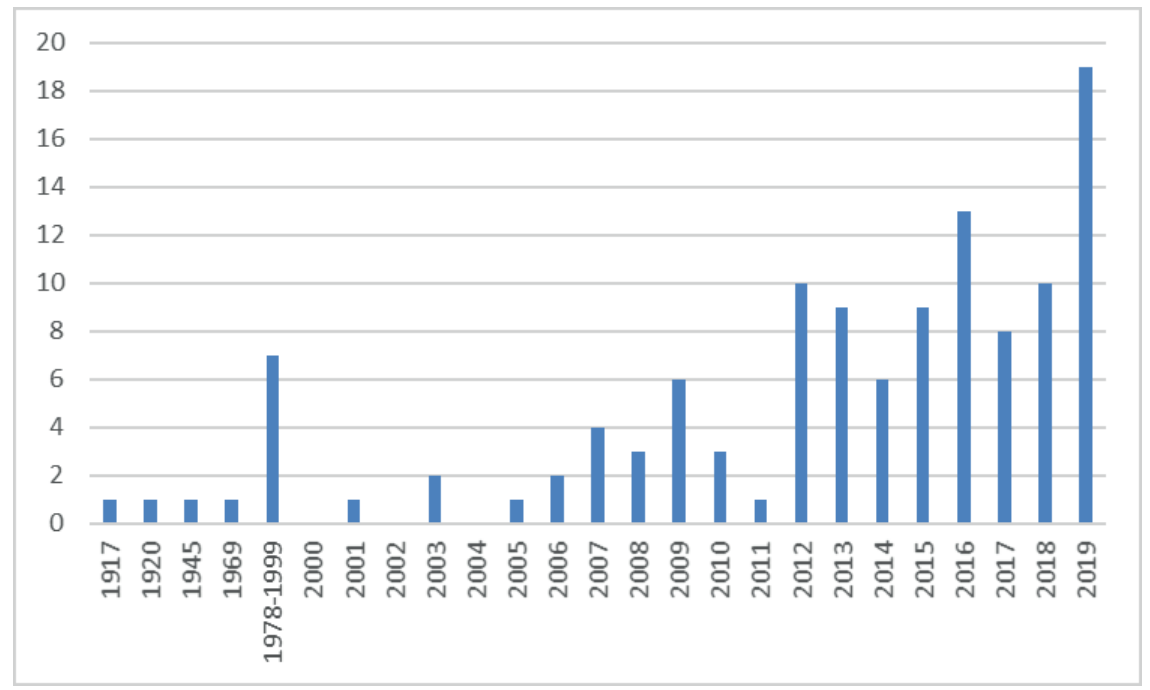

Number of named companies in the data in accordance with the year of establishment

I have analyzed the semantic schemes which the brand names, with special attention focused on the rhetorical function of the emerging direct and indirect meaning relations of the names and their referent companies.

${ }^{3}$ I would like to acknowledge the generosity of Eeva-Leena Pohls, who gave me the list of responsible textile companies she studied for her Master's thesis. 
For the analysis, I have taken from their websites information about the companies, and the stories on their names as well. In marketing, consumer businesses increasingly seek to persuade clients with stories. Storytelling is a fundamental way to make sense of our experiences, to organize them, and thus to catch people's attention. A successful brand tells an interesting story — not only about products but also about the company, its culture, and its values, and about the people behind the company. Stories make meanings and build frames in which brands can be embedded (e.g., Lundqvist et al., 2013; Sax, 2006; Barthes, 1975). Two-thirds of the textile enterprises in this study have given their story on their websites, and most of these stories include some kind of explanation to the brand name as well. I have relied on these stories in my name analysis. I have analyzed the names that do not have any story or explanation on the websites, only on the basis of their linguistic form: some of these are clear even without any contextual knowledge, but some remain opaque.

\section{FINDINGS}

First, I will look at the chosen languages in my data. It is significant, regarding the messages that company names convey, whether the name is in the native language of the consumers or in some foreign language. As mentioned, the language of a name can be seen as a statement about brand identity. After that, I will examine what kind of direct and indirect meaning schemes the names have, paying special attention to the discursive role of the meaning schemes. Finally, I will look at the neologisms in the names, and consider their semantic and discursive role.

\section{Language Choice}

Many of the names in my data are completely Finnish (37/114) or include Finnish elements with elements of some other language (14/114). In addition, some names consist of a Finnish toponym or toponym-like element. English names are also typical: 14 names include English words only, and 28/114 names either have English words combined with other languages or include recognizable parts of English expressions. Some names have both Finnish and English, for instance Aarrelabel (aarre 'treasure') and Mainio Clothing (mainio 'wonderful'). Sometimes English is even combined with dialectal form of a Finnish word: Oikiat Design, which has the dialectal plural form of the word oikea 'correct, right'. There are also names in Latin (e.g. Vestiarium), French (e.g. Jolier), and in a few other languages. I have categorized 25/114 names as being in a quasi language, and 20/114 names as consisting of a personal name, or part of one, usually combined with some other linguistic elements. 
It is not always easy to define the language of these names due to many reasons. International words are a part of many languages (for instance, design and studio are common loanwords in Finnish). There are also coinages that are actually not words of any language, but they still follow Finnish word formation rules (e.g. Luppaset, which has no "meaning" but is reminiscent of other similar nominative plural forms of Finnish words with the diminutive suffix -set, such as kukkaset 'little flowers'). Some names are clearly Finnish, but have an unconventional orthography (e.g. Hurmås neule 'ecstasy knit', instead of hurmos). There are also names that include a Finnish personal name that is also a Finnish word with a meaning of its own: an example of this is Kanto Design, which includes the entrepreneur's family name Kanto, meaning 'tree stump'. Should this kind of name be categorized as Finnish, multilingual (Finnish + English), or a combination of a personal name and an international word? Consequently, it is impossible to offer an exact quantitative overview of the distribution of different languages in the data. However, it is clear that in the names of sustainable clothing companies in Finland, the local language (Finnish) and an international language (English) are together dominant with different types of neologisms and company owners' personal names.

\section{Direct Meaning Scheme}

Some brand names in my data have an informative function and thus, directly reveal certain aspects of the company in question. These names have a direct meaning relationship to the cognitive domain evoked by the referent. A name having a direct relationship to the company can include the following elements: 1) the company owner's name (Anna Ruohonen, the designer's name), 2) a place name that reveals the location of the company (Lapuan kankurit ' ${ }^{\circ}$ Lapua + GEN weavers'), 3) a word that reveals the branch of business or the main product or service of the company (Lapuan kankurit; Jokipiin Pellava 'Jokipii+GEN linen'; Merinovillakauppa 'merino wool shop'), or 4) a word that reveals the company's operating principle (Upcycler Helsinki). These types of names have a practical function in marketing discourse. The names probably appeal to customers who value simple benefits that clothes can produce: ease of purchase, wear and care.

In general, toponyms and anthroponyms are often used as brand names, and they are bound to country-, place- or gender-related stereotypes (Teutsch, 2008). However, to consumers, local place names, such as Finland's capital name Helsinki, the town name Lapua or the village name Jokipii, may carry individual and communal identity, and as such, they represent continuity and longevity and incorporate feelings of togetherness and belonging somewhere (see Hakala et al., 2015). 
They can also appeal to consumers because they represent a counterforce to globalization (Teutsch, 2008). Therefore, familiar place names in brand names can give the consumer an assertion about the brand's reliability: a brand having the same local identity as the customer does must be safe and secure. It also highlights the brand's responsibility: it may indicate that the company gives work to one's fellow citizens, and thus bears social responsibility.

In a few cases, the location of the company is only expressed in the name secondarily, with an abbreviation of the toponym (e.g. Tam-Silk, a silk factory that is located in Tampere). These kinds of names can act similarly at a restricted local level where the underlying toponym is recognizable.

A personal name as a brand name is like the signature of a responsible actor, it guarantees the quality of the products. According to Lowry, the rhetorical effect of a brand named after a person is that it builds an affective relationship between a company and its clients (2016). Nine names show, in some form, the entrepreneur's forename (e.g. MariMari Collection, the owner's name Mari; BYPIAS, the owner's name Pia), surname (Kanto Design; Arela) or the full name (Anna Ruohonen; LAURIJARVINENSTUDIO, the owner's name Lauri Järvinen).

In addition, several names consist of an anthroponym that has no direct connection to the company (e.g. Emmy) or is in some other way difficult to linkto the person behind the company, even though his or her name is part of the brand name (e.g. Sasta < family name Saastamoinen). Instead of a direct one, these names have an indirect meaning relationship to their referents.

Indirect Meaning Scheme - Metaphor, Metonymy, and Symbolization

The majority of names in the data consist of recognizable words representing an indirect meaning scheme. Their linguistic form stimulates certain conceptual domains, which one needs to connect to the domains that the referent, the company, evokes.

The meaning relationship is sometimes metonymic - in other words, the meaning of the word(s) in the name in some way or another is related to or located in the same domain as the company and its activity. Typically, the scheme is A FEATURE OF A PRODUCT REPRESENTS THE COMPANY: e.g. 1 $^{\text {st }}$ Comeback (a store reselling vintage clothes that have made a comeback), Alpa (designs and sells clothes made from alpaca), Kude (designs clothes for curvy ladies, includes a Finnish word kude 'weft', which in the plural kuteet is 'clothes' in slang; also another possible interpretation may be kurvikas 'curvy' + design), and Oldie (thrift store). I also interpret the scheme A TOOL REPRESENTS THE COMPANY as metonymic: e.g. Vaatepuи (rental service for clothes, Finnish vaatepuu 'clothes-hanging stand'), Rekki (a thrift store, Finnish rekki 'clothes rack'). 
A metaphoric meaning scheme combines the cognitive domain evoked by the company with a different one evoked by the name form. It creates a novel structure, which highlights some features of the target domain, the company, and fades out some other features (Lakoff \& Johnson, 1980). For instance, if the brand name compares the company to nature, it may highlight features of the company such as purity, tranquility and naturalness - but fades out, for instance, technology, moneymaking, and waste. There are several names in the data that represent the scheme THE COMPANY IS A PART OF NATURE: e.g. Hilla clothing (makes clothes for children, Finnish hilla 'cloudberry'), Lumipyry (makes products from merino wool, Finnish lumipyry 'whirling snow'), Рарu (makes clothes for children, Finnish papu 'bean'). One common metaphoric scheme is THE COMPANY IS A POSITIVE FEELING: e.g. Lumoan (designer, Finnish lumoan 'I will charm'), Niinmun (designer, Finnish dialectal niin mun 'so mine'), Jouten (designs and makes leisurewear, Finnish jouten 'idle'), and Relove (a thrift store). There are also names that represent the meaning scheme THE COMPANY IS A PLACE, such as Citaroom ${ }^{4}$ Cocoon House, Kätkö Vintage (Finnish kätkö 'cache'), Myssyfarmi (Finnish myssy 'wooly cap' + farmi 'farm'), The Maker Bazaar.

However, the data includes a great deal of brand names which evidently convey indirect associations that are not clearly metonymic or metaphoric by nature. Instead, the meaningful words in the names symbolize the company in many other ways. For example, Hellapuu ('firewood for a stove') designs and makes clothes for women and children, and the company's background story explains that the brand name evokes the good old times: "the clothes are lovely treasures; just like the ones mom or grandma has sewn". 5 Thus, through this name, the brand is connected to the conceptual domain of past times, with such concepts as calm living, handicrafts, the countryside, modesty and so on. Another kind of symbolic meaning is in the Finnish brand name Hujaus ('very short time, quick movement'). The company makes clothes for women who are breastfeeding. With this name, the company highlights the short time infants are small and the mother will need clothes for breastfeeding. At the same time, the company emphasizes that its core idea is to make clothes that will last and be used more than once. A third example of such complex connections between name and referent is PaaPii, the name of a company that designs and makes children's clothes. When Finnish children play as if they are driving an emergency vehicle, they imitate the sound with the onomatopoeic form of a siren: piipaapiipaa. The name connects the company to the conceptual domain of children's play and symbolizes the target group for the company's products.

${ }^{4}$ NB. The name may have a connection to the Indonesian river name Citarum, as well. The river is heavily polluted by the textile industry (Natahadibrata, 2013).

${ }^{5}$ https://www.hellapuu.fi/fi/tietoa-meista; translation by the author. 


\section{Neologisms and Their Semantic Role}

Brand names that consist of neologisms or abbreviations are more difficult to analyze semantically. These expressions might include parts of some words that are quite recognizable and, as such, convey meanings connected to these words, but they can also be seemingly artificial quasi-words (e.g. Kaiko) or abbreviations (e.g. $R / H$ Studio) that bear no meaning. However, their phonological form might evoke some associations: for example, Uhana is reminiscent of the Finnish compound uhan|alainen 'threat + subordinate', 'endangered', and Zadaa sounds like a shout interrelated with rapid action. Sometimes the "meaning" of such a name is explained on the company's website: for example FRENN Helsinki, which designs menswear, comes from the words "fresh and Nordic", Lovent comes from the slogan "love the movement", and Weecos comes from the words "we ecos".

Occasionally, a company name can appear to be a quasi-word for Finnish consumers but it actually consists of a word of some real language, the meaning of which the company has explained on its website. Some examples include Atelier Laleh, a designer and garment maker, including the Persian word laleh 'tulip' ${ }^{6}$ and a company called Népra, which designs sportswear, and according to the company, "Népra is (sic.) Carelian and means water".

Finnish is an agglutinative language with a great deal of endings. Sometimes a brand name is obviously an inflected form of a Finnish word - either a verb or a noun (e.g. Lumoan, first-person singular of the verb lumota 'to charm'). However, because proper names usually include words in the nominative, it is not certain that even Finnish consumers could figure out the content. Instead, they might think that the name includes a quasi-word. For example, Nouki can be interpreted as including the second-person singular imperative of the noukkia 'to pick up', but it is not easy to say if this was actually the intention of the company, as there is no explanation for the name on the website.

Neologisms, quasi-words, and abbreviations as brand names allow broader semantic interpretations as names, which include clear recognizable words and names. They are easy to hold as just labels referring to the brand without any semantic content. However, they might also evoke many associations in different consumers' minds, especially when the consumer associates a certain company's name with particular features, such as sustainability. Even though the name Uhana does not "mean" anything, knowing that the company values environmental and social sustainability ${ }^{8}$ makes it easy to connect the name to the Finnish word $u h a$ nalainen 'endangered'.

\footnotetext{
${ }^{6} \mathrm{https}: / /$ www.atelierlaleh.com/story

7 https://neprablog.wordpress.com/2017/07/17/the-secrets-of-frog/

${ }^{8} \mathrm{https} / / /$ www.uhanadesign.com/en/about-us/
} 


\section{DISCUSSION: NAME SEMANTICS AND RESPONSIBLE BUSINESS IDEOLOGY}

In the introduction, the following two research questions were stated:

1) Can ideological values be seen in the names of sustainable textile companies?

2) In what ways do the brand names convey environmental sustainability?

In order to answer these questions, I have analyzed the meaning schemes and language choices of the brand names above in my data. I this section, I will connect the findings of this semantic analysis to the contemplation of which discursive functions the names have, and to which extent they function in environmental sustainability discourse or in responsibility discourse.

The answer to question 1 is positive: over one-quarter (about 30/114) of the names in the data have either a direct or an indirect meaning relationship or a readable connection in some other way to the environmentally sustainable values of the company. I will come to these names below. Before that, it should be noted that many names (about 40/114) are semantically connected to clothes, fabrics, garment makers, users or ways of use without any reference to sustainability discourse: for example Formal Friday, The Other Danish Guy, ${ }^{9}$ Shy Vibes Club, MEA (Latin 'mine'), Vestis (Latin 'garment'), Knokkon (makes nettle and hemp textiles, Fi nokkonen 'nettle'). The remaining data evoke miscellaneous associations (e.g. Pixie Dust, Nudge, Nomen Nescio Latin 'I don't know the name', MOIMOI, a Finnish salutation) or do not have any obvious semantic link to any word (e.g. MEM, Wiwi Design).

Brand names can also directly convey the sustainable ideology of the company. For instance, the name Pure Waste directly expresses the material of the products: the company manufactures and sells yarn, fabrics and garments made from $100 \%$ recycled materials, that is, materials that would otherwise go to waste. The circular economy is also behind the name Upcycler Helsinki, which directly refers to the fact that the company sells fashion products made from recycled materials, ${ }^{10}$ and that the company is located in Helsinki. In addition, Vähänkäytetty ('slightly used' in Finnish) as well as Vintage Magasinet ('vintage store' in Swedish), $1^{\text {st }}$ Comeback, Oldie and Remake EkoDesign have a direct relationship to the qualities of the companies' products. These names explain to customers what they can expect, and they can appeal directly to the customers' ideological values.

9 The name refers to the company owners; see the extraordinary background at https://theotherdanishguy.eu/pages/brand

10 "Upcycling means recycling recycled material into something new even better. That is what I wanted to promote with my company; recovery of the old both qualitatively and aesthetically" (https://en.upcyclerhelsinki.com/pages/upcycler-helsinki-verkkokauppa). 
The concept of environmental sustainability contains many aspects. Saving natural resources and diminishing global waste by recycling is one aspect, but protecting biodiversity, preventing pollution and carbon emissions, and keeping the planet in balance for future generations are equally important. If a company wishes to appeal to customers who value sustainable development, it is advisable to have a name that permits broad associations, and at the same time, indirectly leads the customers to the company through the conceptual domains of nature, Earth, and the good life. The many brand names that include a word meaning a part of nature, as mentioned above, act in marketing discourse as signs of loving nature and caring for it. Names such as Cocoon House, Weekendbee, Savana Collection and Lumipyry ('whirling snow'), which have words that are in the conceptual domain of endangered natural phenomena, are particularly evoking.

A clear indication of the metaphoric and symbolic nature of a name is how Globe Hope, a company that designs and sells products made from recycled materials, defines itself in its story (example 1).

(1) We are Globe Hope. This is not only a name, but the mindset we share. We are the forerunners in uncompromisingly sustainable design. ${ }^{11}$

The company uses the name as predicate complement of the definition sentence (we are $X$ ) and then makes sure that it is understood as a meaningful phrase (not only a name but). From a marketing discourse point of view, it is noteworthy that instead of speaking in the third person (company/enterprise/etc. is called X) one can see the first-person pronoun we twice and copula are in the text, which underlines people who act in the company and have certain values and qualities (forerunners in uncompromisingly sustainable design).

\section{CONCLUSION}

In marketing discourse, company and brand names are an important part of persuasive rhetoric. They simultaneously must be distinctive in order to distinguish the brand from others and communicative in order to convey the benefits, the value, that people will attain by buying their products. The value can be functional, but it can also arise from simply possessing certain products, which means that the product has important symbolic, identity-bound features for the customer (Woodruff \& Gardial, 1996). Environmentally sustainable development may be one of such features.

\footnotetext{
11 https://globehope.com/pages/about-us
} 
This study has shown that Finnish fashion brands based on environmental sustainability also frequently express the values in their names. According to Teutsch, there has been a change in commercial names from a materialistic-oriented to a more sustainable view in the first decade of the $21^{\text {st }}$ century (2008). Generally speaking, all brand names that can in some way be connected to sustainability do not actually represent the company's values but may be a kind of greenwashing. However, the data in my study represent companies that outside experts have recognized as sustainable ones.

According to Teutsch, who has studied a group of brand names taken from the Swiss national trademark register, the use of place names especially in brand names together with morpho-phonological elements referring to nature, displays the values of sustainability (2008). However, this is not typical for the names in my data. Instead, the company names convey sustainable values in many ways: by using the company owner's or designer's personal name as a guarantee, by using a local place name for indicating opposition to globalization, or by using words or recognizable parts of words for evoking associations to circular economy, global climate change or biodiversity of nature.

\section{REFERENCES}

Ainiala, T., Saarelma, M., \& Sjöblom, P. (2012). Names in Focus. An Introduction to Finnish Onomastics. Helsinki: Finnish Literature Society.

Barthes, R. (1975). An introduction to the structural analysis of narrative. New Literary History, $6(2), 237-272$.

Bergien, A. (2008). Global and regional considerations in the formation of company names. In Atti del XXII Congresso Internazionale di Scienze Onomastiche (Vol. II, pp. 289-297). Pisa: Edizioni Ets.

CICAT2025. Circular Economy Catalysts: From Innovation to Business Ecosystems. Turku University of Applied Sciences. https://cicat2025.turkuamk.fi/en/

EMF 2017 = A New Textiles Economy: Redesigning Fashion's Future. Ellen MacArthur Foundation. http://www.ellenmacarthurfoundation.org/publications

EU $2020=$ A New Circular Economy Action Plan. For a cleaner and more competitive Europe. Communication from the Commission to the European Parliament, the Council, the European Economic and Social Committee and the Committee of the Regions. Brussels: European Commission, 11.3.2020. https://eur-lex.europa.eu/legal-content/EN/TXT/?qid=1583933814 386\&uri=COM:2020:98:FIN

Evans, V., \& Green, M. (2006). Cognitive Linguistics: An introduction. Edinburgh: Edinburgh University Press. ProQuest Ebook Central.

FINIX = List of sustainable textile companies in Finland. https://finix.aalto.fi/kestavavaate-kampanja/ (25.02.2021).

Finnish Government (2019). Inclusive and Competent Finland - a Socially, Economically and Ecologically Sustainable Society. Publications of the Finnish Government 2019: 25. https:// julkaisut.valtioneuvosto.fi/handle/10024/161664 
Hakala, U., Sjöblom, P., \& Kantola, S.P. (2015). Toponyms as carriers of heritage: implications for place branding. Journal of Product \& Brand Management, 24(3), 263-275. https:// dx.doi.org/10.1108/JPBM-05-2014-0612

Lakoff, G., \& Johnson, M. (1980). Metaphors We Live By. Chicago: University Press.

Langacker, R.W. (1987). Foundations of Cognitive Grammar (Vol. I). Stanford: Stanford University Press.

Lowry, E. (2016). Eponymous elixirs: Mrs. Pinkham, nineteenth-century patent medicines, and the rhetoric of naming. In S. M. Vanguri (Ed.), Rhetorics of Names and Naming. Routledge Studies in Rhetoric and Communication, 28 (pp. 170-181). New York-London: Routledge.

Lundqvist, A., Liljander, V., Gummerus, J., \& van Riel, A. (2013). The impact of storytelling on the consumer brand experience: The case of a firmoriginated story. Journal of Brand Management, 4(4), 283-297.

Mattfolk, L. (2017). Attitudes towards globalized company names. In T. Ainiala, \& J.O. Östman (Eds.), Socio-onomastics: The pragmatics of names (pp. 165-181). Amsterdam: John Benjamins Publishing Company.

Montes Fernández, A. (2008). Marken- und Produktnamen der Glamour-Industrie im sozio-ökonomischen Diskurs. Onoma, 43, 195-220.

Natahadibrata, N. (2013, November 6). Citarum, Kalimantan world's most polluted. Jakarta Post. https://www.thejakartapost.com/news/2013/11/06/citarum-kalimantan-world-s-most-polluted.html

Park, C.W., MacInnis, D.J., \& Eisingerich, A.B. (2016). Brand Admiration: Building a business people love. Hoboken-New Jersey: John Wiley \& Sons.

Peréz Hernández, L. (2011). Cognitive tools for successful branding. Applied Linguistics, 32(4), 369-388.

Pérez Hernández, L. (2013). A pragmatic-cognitive approach to brand names. A case study of Rioja Wine Brands. Names, 61(1), 33-46.

Rosteck, T. (1999). Introduction. In T. Rosteck (Ed.), At the Intersection: Cultural studies and rhetorical studies (pp. 1-24). New York: Guilford.

Šajn, N. (2019). Environmental Impact of the Textile and Clothing Industry. What consumers need to know. Members' Research Service PE 633.143. European Parlament. https://www.europarl. europa.eu/RegData/etudes/BRIE/2019/633143/EPRS_BRI(2019)633143_EN.pdf

Sax, B. (2006). Storytelling and the 'Information Overload'. On the Horizon, 14(4), 165-170.

Sjöblom, P. (2006). A cognitive approach to the semantics of proper names. Onoma, 41, 63-82.

Sjöblom, P. (2016). Commercial names. In C. Hough (Ed.), The Oxford Handbook of Names and Naming (pp. 453-464). Oxford: Oxford University Press.

Teutsch, A. (2008). Trademarks as indicators of the Zeitgeist. Onoma, 43, 251-275.

Vanguri, S.M. (2016). Introduction: toward a rhetorical onomastics. In S. M. Vanguri (Ed.), Rhetorics of Names and Naming (pp. 1-10). New York: Routledge.

Virsu, V. (2012). Sitouttamisretoriikka yritysviestinnässä [Commitment Rhetoric in Corporate Communications]. Turku: University of Turku.

Woodruff, R.B., \& Gardial, S.F. (1996). Know your Customer. New Approaches to Understanding Customer Value and Satisfaction. Oxford: Blackwell.

Zilg, A. (2013). «Tu y yo». Aspects of brand names related to interaction and identification. In P. Sjöblom, T. Ainiala, \& U. Hakala (Eds.), Names in the Economy. Cultural prospects (pp. 269-281). Newcastle: Cambridge Scholars. 


\section{SUMMARY}

COMMUNICATING WITH BRAND NAMES IN THE SUSTAINABLE FINNISH FASHION INDUSTRY

The global textile industry has a significant environmental impact since the current system for producing, distributing and using clothing exhausts natural resources. However, while there has been a growing awareness of negative environmental impacts among customers, more and more clothing companies have aligned themselves with the principles of sustainability. This paper investigates whether and how clothing companies express the notion of environmental sustainability in their names. The data consist of 114 company and brand names in the sustainable Finnish textile industry, supplemented with information taken from the webpages of these companies. The analysis focuses on the semantic features of the names, and it is based on a cognitive-discursive view and metaphor theory. The choice of language has been examined as part of name semantics.

Many companies have written the story behind the brand name on their website. Names can convey direct notions of sustainability and circular economy (Pure Waste, Relove, Upcycler). Names that consist of words referring to nature (Cocoon house, Weekendbee) have an indirect relation to corporate sustainability. Some names consist of a personal name, which underlines the responsibility of the brand, or a place name, which may highlight locality. Valuing local production is also behind the choice of Finnish as the language of the name. 